\title{
Epimutations in human sperm from patients with impaired spermatogenesis
}

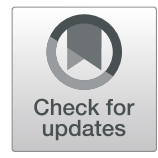

Joana Marques ${ }^{1,2^{*}} \mathbb{D}$, Filipa Carvalho ${ }^{1,2}$, Alberto Barros ${ }^{1,2,3}$ and Mário Sousa $a^{3,4}$

In this Letter to the Editor, we comment on the recent publication by Leitão et al. The sperm epigenome does not display recurrent epimutations in patients with severely impaired spermatogenesis (Clinical Epigenetics 2020, DOI: 10.1186/s13148-020-00854-0), where concerns about the validity of our studies reporting imprinting errors in human sperm from infertile patients have been raised.

We read with great interest this recent publication describing genome-wide methylation in human sperm from oligozoospermic patients, which could be an important resource to understand the extent of methylation defects and whether these are restricted to imprinted genes.

However, we were surprised to find that the Authors attributed imprinting methylation errors to contamination of somatic cells and even stated that they "suspect that other studies also suffer from DNA contamination issues".

Thereby, we would like to clarify that, in our studies, in order to eliminate somatic cell contamination, we have prepared sperm by density gradient centrifugation (DGC) (using density gradients) prior to swim-up separation, as we previously described $[1,2]$. The sequential method of DGC swim-up is the elective method for sperm preparation to be used in assisted reproductive treatments (ART) [3]. Additionally, we visually inspected, by optical inverted microscopy with Hoffman modulation contrast, a $20-\mu \mathrm{l}$ droplet of all the samples that were included in our studies, before using sperm samples in experiments.

We noticed that in the study by Leitão and collaborators [4], density gradient separation was not performed and direct swim-up was employed, thereby increasing the

This comment refers to the article available at https://doi.org/10.1186/ s13148-020-00854-0.

* Correspondence: cmarques@med.up.pt

'Department of Genetics, Faculty of Medicine, University of Porto (FMUP), 4200-319 Porto, Portugal

i3S_-Instituto de Investigação e Inovação em Saúde, Universidade do Porto, 4200-135 Porto, Portugal

Full list of author information is available at the end of the article likelihood of having somatic cells contamination in their sperm samples, as is suggestive from the author's WGBS data, including for $\mathrm{H} 19$ methylation values (ranging from 75 to $82 \%$ methylation in normal controls in their study vs $95 \%$ in our study [2]. For density gradient centrifugation, we used Puresperm gradients (Nidacon, Gothenburg, Sweden) which contain silane-coated silica particles that enable motile sperm to be separated from non-germinal cells and seminal plasma. The advantages of the density gradient method is the attainment of an excellent yield of highly motile normal spermatozoa, whereas leukocytes, bacteria, epithelial cells, cell debris, and most abnormal sperm are eliminated, while sperm DNA fragmentation and reactive oxygen species are significantly reduced [3, 5]. In fact, our team has more than 20 years of experience in preparing semen samples for ICSI and to date sperm samples obtained after gradient centrifugation followed by swim-up were never found to be contaminated by leukocytes and, in ICSI, purified sperm are selected individually.

Moreover, in our studies conducted on testicular sperm, that were individually isolated by micromanipulation from testicular biopsies [6, 7], and therefore not contaminated with somatic cells, we have also observed imprinting errors, namely H19 DMR hypomethylation and MEST DMR hypermethylation.

Nevertheless, we agree with the Authors that it is necessary to reassure patients undergoing IVF treatments and our works contributed to this purpose by showing a very low frequency of sperm with completely altered methylation patterns, in infertile patients.

Furthermore, in most of the cases presented in our results, the patient producing sperm with imprinting errors also carried sperm with correct methylation patterns. In the future, we hope to understand how these imprinting errors occur, in order to contribute to improve the safety and efficacy of assisted reproduction techniques. 


\section{Author's response to Marques et al.}

\section{Elsa Leitão, Sara Di Persio, Sandra Laurentino, Marius Wöste, Martin Dugas, Sabine Kliesch, Nina Neuhaus and Bernhard Horsthemke}

Correspondence: Bernhard.horsthemke@uni-due.de

We appreciate the comments by Marques et al. and their efforts to purify spermatozoa, which go far beyond what most researchers in this field do. Most of the previous studies were performed on swim-up samples, and we have found that samples prepared in this way can be contaminated with somatic DNA. Of course, we could not reanalyze the samples that were used by others, but our lack of finding any evidence for an epimutation in 93 sperm samples, which make our study one of the largest in its field, justifies our conclusion that "the prevalence of aberrant methylation in swim-up purified sperm of infertile men has likely been overestimated" [4]. Irrespective of the purification procedure used, the DNA should always be prescreened for somatic DNA contamination by bisulfite sequencing of at least the four genes suggested in our paper (H19, MEST, DDX4, and XIST) or the four genomic loci suggested by Jenkins et al. [8].

Unfortunately, Marques et al. have not considered genetic variation as another confounder in this type of studies. As shown by us, a common genetic variant at the $H 19$ locus is associated with DNA hypomethylation, which should not be confused with an infertilityassociated epimutation [4].

\section{Abbreviations}

DGC: Density gradient centrifugation; ART: Assisted reproductive treatments; WGBS: Whole-genome bisulfite sequencing; ICSI: Intracytoplasmic sperm injection; DMR: Differentially methylated region; IVF: In vitro fertilization

\section{Acknowledgements}

Not applicable.

\section{Authors' contributions}

CJM, FC, AB, and MS wrote, read, and approved the final manuscript.

\section{Funding}

CJM is funded by the Portuguese Foundation for Science and Technology (FCT) with a salary contract (IF/00047/2012; CEECIND/00371/2017).

Availability of data and materials

Not applicable.

Ethics approval and consent to participate

Not applicable.

\section{Consent for publication}

Not applicable.

\section{Competing interests}

The authors declare that they have no competing interests.

\section{Author details}

'Department of Genetics, Faculty of Medicine, University of Porto (FMUP), 4200-319 Porto, Portugal. ${ }^{2}$ i3S — Instituto de Investigação e Inovação em Saúde, Universidade do Porto, 4200-135 Porto, Portugal. ${ }^{3}$ Centre for
Reproductive Genetics A Barros, 4100-009 Porto, Portugal. ${ }^{4}$ Department of Microscopy, Laboratory of Cell Biology, Multidisciplinary Unit for Biomedical Research-UMIB, Institute of Biomedical Sciences Abel Salazar (ICBAS), University of Porto, Rua Jorge Viterbo Ferreira, 228, 4099-003 Porto, Portugal.

Received: 1 July 2020 Accepted: 17 August 2020

Published online: 17 November 2020

References

1. Marques CJ, Carvalho F, Sousa M, Barros A. Genomic imprinting in disruptive spermatogenesis. Lancet. 2004;363(9422):1700-2.

2. Marques CJ, Costa P, Vaz B, Carvalho F, Fernandes S, Barros A, et al. Abnormal methylation of imprinted genes in human sperm is associated with oligozoospermia. Mol Hum Reprod. 2008;14(2):67-74.

3. Bucar S, Goncalves A, Rocha E, Barros A, Sousa M, Sa R. DNA fragmentation in human sperm after magnetic-activated cell sorting. J Assist Reprod Genet. 2015;32(1):147-54.

4. Leitao E, Di Persio S, Laurentino S, Woste M, Dugas M, Kliesch S, et al. The sperm epigenome does not display recurrent epimutations in patients with severely impaired spermatogenesis. Clin Epigenetics. 2020;12(1):61.

5. Henkel RR, Schill WB. Sperm preparation for ART. Reprod Biol Endocrinol. 2003:1:108.

6. Marques CJ, Francisco T, Sousa S, Carvalho F, Barros A, Sousa M. Methylation defects of imprinted genes in human testicular spermatozoa. Fertil Steril. 2010;94(2):585-94

7. Marques PI, Fernandes S, Carvalho F, Barros A, Sousa M, Marques CJ. DNA methylation imprinting errors in spermatogenic cells from maturation arrest azoospermic patients. Andrology. 2017;5(3):451-9.

8. Jenkins TG, Liu L, Aston Kl, Carrell DT. Pre-screening method for somatic cell contamination in human sperm epigenetic studies. Syst Biol Reprod Med. 2018:64:146-55.

\section{Publisher's Note}

Springer Nature remains neutral with regard to jurisdictional claims in published maps and institutional affiliations.
Ready to submit your research? Choose BMC and benefit from:
- fast, convenient online submission
- thorough peer review by experienced researchers in your field
- rapid publication on acceptance
- support for research data, including large and complex data types
- gold Open Access which fosters wider collaboration and increased citations
- maximum visibility for your research: over 100M website views per year
At BMC, research is always in progress.
Learn more biomedcentral.com/submissions 